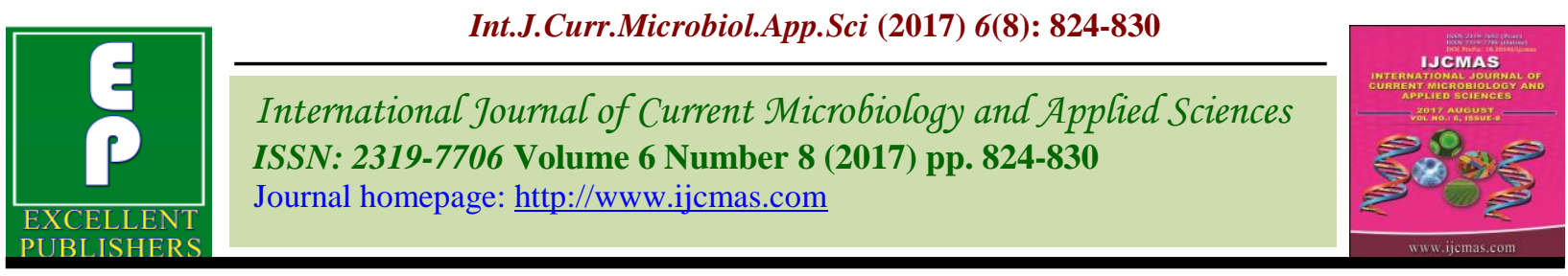

Original Research Article

https://doi.org/10.20546/ijcmas.2017.608.104

\title{
Enumeration of Gut Bacterial Population in Eisenia fetida Exposed to Chlorpyrifos
}

\author{
Jyoti Yadav $^{1}$, Dharambir Singh ${ }^{1}$, Swati Sindhu ${ }^{2}$, Rajesh Gera ${ }^{2}$ and Shefali ${ }^{1}$ \\ ${ }^{1}$ Department of Zoology, ${ }^{2}$ Department of Microbiology, \\ CCS Haryana Agricultural University, Hisar- 125004, India \\ *Corresponding author
}

\section{A B S T R A C T}

\begin{tabular}{|c|c|}
\hline Keywords & \multirow{5}{*}{$\begin{array}{l}\text { The present study was carried out to envisage the impact of chlorpyrifos on gut bacterial } \\
\text { population of } E \text {. fetida. The LC } \mathrm{C}_{50} \text { of chlorpyrifos was analyzed by } 24 \text { hour paper contact } \\
\text { toxicity test as recommended by OECD. The } \mathrm{LC}_{50} \text { of chlorpyrifos for } 24 \text { hours is } 0.25 \% \text {. } \\
\text { Then the worms were exposed to the LC } \mathrm{C}_{50} \text { dose, one dose lower }(0.125 \%) \text { and one dose } \\
\text { higher }(0.375 \%) \text { of chlorpyrifos. The samples of gut from treated worms were cultured on } \\
\text { nine different culture media viz. Mac Conkey Agar, LB media, R.S. Media, King's B } \\
\text { media, YEMA, Jensen media, Malatemedia, Endo agar media and nutrient agar media. } \\
\text { Significant differences in total viable bacterial count on Luria Bertani and King's media } \\
\text { has been observed in earthworms exposed to lowest dose (T1) of chlorpyrifos as compared } \\
\text { to control. However, when the worms were exposed to highest dose (T3) significant } \\
\text { reduction in total viable counts was observed in comparison to control except on Endo } \\
\text { Agar media. It may also be noted that greater number of viable counts was observed in } \\
\text { vermicompost (VC) samples as compared to those present in worm's gut. }\end{array}$} \\
\hline $\begin{array}{l}\text { Bacteria, } \\
\text { Chlorpyrifos, } \\
\text { Insecticide, } \\
\text { Eisenia fetida, } \\
\text { CFU. }\end{array}$ & \\
\hline Article Info & \\
\hline & \\
\hline $\begin{array}{l}\text { Available Online: } \\
10 \text { August } 2017\end{array}$ & \\
\hline
\end{tabular}

Introduction

Earthworms being the most efficient soil organism to improve soil fertility by burrowing deeply into subsoil surfaces and then releasing it out in the form of nutrient enriched cast (Lavelle, 2011). As they are abundant in number and highly productive species, so they are keystone species in the food web of soil environment (Thakuria et al., 2010). Earthworm burrows and drilosphere act as microhabitats for soil invertebrates like nematodes (Andriuzzi et al., 2016), arthropods (Boivin et al., 2006). Drilosphere and burrows are also the microbial hotspots of soil (Schrader et al., 2007), which improves the soil ecology. The role of earthworms to degrade organic waste, mixing of subsoil, stabilizes the aggregates of soil and improving the porosity of soil, has led their increased use in vermicomposting (Yadav et al., 2017a). Vermicomposting being ecofriendly, economical and self-regulated technique offers better option to reduce the waste into organic manure (Yadav et al., 2017b). Unlike composting, vermicomposting establishes suitable environment for microbes and worms to flourish. During the initial phase of vermicomposting, earthworms rely on friendly microbes to rot and decay the waste, thereby making it suitable for ingestion. Once the food is ingested, the endosymbiotic gut microbial community helps in digestion of organic waste (Yadav 
and Gupta, 2017). However, the survival of earthworms has been threatened due to indiscriminate use of pesticides. Chlorpyrifos belongs to organophosphate group of pesticides and causes toxicity by inhibiting enzyme acetylcholinesterase in earthworms (Rao et al., 2003). Due to their wide distribution in soil, earthworms have been recommended as suitable organism for ecotoxicological assessments by OECD (Zhang et al., 2014). Being contact insecticide, chlorpyrifos enters the body of worm and may cause alterations in gut bacterial population. Owa et al., (2013) has stated that efficacy of bacterial action is better when they act in gut of earthworms in comparison to their direct in vitro action. Therefore, the presence of endosymbiotic bacteria in worm's gut has huge importance for the process of vermicomposting. Aira et al., (2016) stated that the decomposition process is influenced by the microbial diversity present in gut. Hence, the present study has been carried out to envisage the impact of chlorpyrifos toxicity on the gut bacterial population of earthworms.

\section{Materials and Methods}

\section{Procurement of test organism and chemicals}

To avoid the incidence of pre exposure of pesticides, fully clitellated healthy earthworms (with average weight of $500 \mathrm{mg}$ ) of third generation were obtained from the Vermiculture Unit of Department of Zoology, CCS Haryana Agricultural University, Hisar. The technical grade chlorpyrifos (20 EC) was obtained from the Department of Entomology, College of Agriculture, CCS Haryana Agricultural University, Hisar. Nine media viz. Yeast Mannitol Agar (for cultivation of Rhizobium sp.), King's medium (culturing of Pseudomonas), Mac Conkey Medium (E. coli), R. S. medium, Luria Bertani Agar medium (for E. coli),
Azospirillum medium (for culturing Azospirillum), Endo agar medium (for coliform bacteria), Jensen Medium (for nitrogen fixing bacteria) and Nutrient Agar medium were procured from $\mathrm{Hi}$ Media Laboratories Pvt. Ltd., Mumbai (India) and sterilizedfor estimation of total bacterial population of worm's gut and vermicompost.

\section{Determination of $\mathbf{L C}_{50}$}

The $\mathrm{LC}_{50}$ of chlorpyrifos was estimated by standard paper contact toxicity test in accordance with OECD guidelines (1984). The earthworms were washed with distilled water and kept on moist filter paper for three hours to ensure the voiding of gut contents. The sides of flat bottomed glass vials $(8 \mathrm{~cm} \times$ $3 \mathrm{~cm})$ were lined with the medium grade ( $0.2 \mathrm{~mm}$ thick) filter paper of proper size so as to avoid the overlapping of filter paper. Different concentrations of chlorpyrifos $(0.002 \%, 0.04 \%, 0.06 \%, 0.08 \%, 0.1 \%, 0.12 \%$, $0.14 \%, 0.16 \%, 0.18 \%$ and $0.20 \%$ ) were prepared and filter paper coated glass vials were poured with one $\mathrm{ml}$ of each concentration. Thereafter, vials were rotated horizontally to ensure the homogenous distribution of insecticide on filter paper followed by release of one earthworm per vial. Proper aeration, temperature $\left(20 \pm 2^{\circ} \mathrm{C}\right)$ and moisture were maintained during the experiment to minimize the mortality in control and exposure to light was minimized to increase the efficiency of experiment. Eight replicates for each concentration along with the control (having deionised water) were maintained. Post treatment morphological and behavioral changes were recorded at appropriate time intervals. Mortality was checked after 24 hours and percent mortality was calculated, the corrected mortality was computed by the formula given by Abbott (1925) and the data thus reported during experiment were subjected to Probit analysis (Finney, 1971). 


\section{Collection of sample}

The earthworms were collected by hand sorting method, washed with distilled water and then exposed to chlorpyrifos on filter paper (coated with various concentrations of insecticide) fitted vials. After one hour of exposure, worms were cleaned externally with alcohol in order to avoid the alteration due to surrounding bacteria. Thereafter, worms were pinned down horizontally with ventral part upside and gut portion was identified. The dissected gut was used for preparation of serial dilutions. The vermicompost sample was collected from the vermicomposting unit and dried for further analysis. The description of various treatments given to worms has been depicted in table 1.

\section{Determination of total viable bacterial counts}

$1 \mathrm{gm}$ of the gut contents were transferred to 9 $\mathrm{ml}$ of distilled water and shaken properly. The dilutions of $10^{-4}$ were prepared by following this step repeatedly. Similarly, the sample of vermicompost was also diluted serially to compare the bacterial counts of vermicompost with those present in earthworm's gut. The $0.1 \mathrm{ml}$ aliquots of diluted bacterial samples obtained from the gut and vermicompost were inoculated on different Petri plates having different medium by pour plate technique. The Petri plates inoculated with the dilutions were then incubated at $28 \pm 2^{\circ} \mathrm{C}$ for 48 hours. The total number of colony forming unit present on the surface of media were counted and expressed as CFU $\times 10^{-4} \mathrm{ml}^{-1}$.

\section{Statistical analysis}

The data reported are the arithmetic mean of triplicates and were subjected to one way ANOVA to analyze the significant difference between different treatments using OPSTAT software developed at CCS Haryana Agricultural University, Hisar.

\section{Results and Discussion}

\section{$\mathrm{LC}_{50}$ of chlorpyrifos on adult Eisenia fetida}

The results of the bioassays clearly marked the rigorous damage potential of insecticides on earthworms. Dose dependent increase in mortality due to insecticide exposure was recorded during the experiment. Nonetheless, the signs of starvation like slightly lethargic body movements were also observed in control worms. The $\mathrm{LC}_{50}$ of chlorpyrifos for 24 hours is $0.25 \%$.

\section{Morphological changes in earthworms on exposure to chlorpyrifos}

Increased mucus secretion along with depigmentation was observed in worms exposed to higher concentrations of chlorpyrifos. Deformity and loosening of posterior metameric segments was noticed in worms on exposure to chlorpyrifos $(0.1 \%$ and above). Thick mucus discharge with body lesions, damaged clitellum, deformed body, intense curling and beaded appearance of posterior segments marked the intense chlorpyrifos toxicity in worms at $0.18 \%$ and above. Changes in morphology due to chlorpyrifos can also be justified by the findings of Rao et al., (2003).

\section{Behavioral changes in earthworms on exposure to chlorpyrifos}

The physiological and biochemical changes in earthworms due to chlorpyrifos exposure resulted in behavioral changes. Notable changes in terms of behavior were observed in worms exposed to lower and higher concentrations of insecticide in comparison to control. The worms exposed to lower concentrations of chlorpyrifos exhibited 
avoidance and escape behavior. Even at slightest exposure, worms exhibited lethargic and sluggish movements, flattened posture with reduced activity. However, restlessness along with jerky movements was observed on exposure to higher concentrations. Since, chlorpyrifos targets the acetylcholinesterase enzyme of the organism; it may be the cause of uncontrolled and jerky movements as stated by Rao et al., (2003).

\section{Assessment of bacterial counts of earthworms' gut and vermicompost}

The total viable bacterial counts were statistically higher in vermicompost sample when cultured on Luria Bertani, King's medium, Azospirillum and Endo Agar medium as compared to those in gut of untreated earthworms. Highest number of total viable counts (175.67 \pm 4.26) was observed in vermicompost sample cultured on nutrient agar medium. Symbiotic relationship between earthworm and gut microbes has previously been stated by Fracchia et al., (2006). However, it may also be noted that the colony forming units found on agar were statistically non- significant to those of control earthworm's gut samples. Nonsignificant difference has been observed in the vermicompost samples cultured on Mac Conkey Agar, R.S. Media, YEMA and Jensen media. The lower viable bacterial counts in gut as compared to vermicompost can be due to the digestion activity on ingested material in worm's gut as stated by Kadam and Pathade (2017). Hindgut has been stated as the most suitable part of gut for microbial multiplication by Owa et al., (2013) and Kadamand Pathade (2017). However, selective activity in worms gut due to presence of digestive enzymes may also contribute to the regulation or modification of microbial communities (Byzov et al., 2007). The results of the total viable bacterial counts in worm's gut on nutrient agar can be justified by the findings of Esakkiamal and Lakshmibai (2013) and Ravindran et al., (2015) in Eudrilus eugeniae. Meharaj and Manivannan (2015) have observed an increased level of microbial population in vermicompost due to the activity of earthworms. The availability of optimum moisture and larger surface area offered by casts leads to better multiplication of microbes. However, the colony forming units found on agar were statistically nonsignificant in comparison to those of control.

Non- significant differences were observed in vermicompost samples cultured on Mac Conkey Agar, R.S. Medium, YEMA and Jensen medium. Positive co relation of diet and habitat of earthworm with the gut bacterial population has been documented by Thakuria et al., (2010). Bacillus, Aeromonas, Pseudomonas, Flavobacterium, Nocardia, Gordonia, Vibrio, Clostridium, Proteus, Serratia, Mycobacterium, Klebsiella, Azotobacter and Enterobacter have been reported by Vega and Victoria (2009). The influence of diet on the gut bacterial diversity has also been previously stated by Bamidele et al., (2014).

Table.1 Description of various treatments used during experiment

\begin{tabular}{lll}
\hline S. No. & Treatment & Description \\
\hline 1. & Control & Worms without pesticide exposure \\
2. & VC & Vermicompost \\
3. & T1 & Worms exposed to $0.125 \%$ of chlorpyrifos \\
4. & T2 & Worms exposed to $0.25 \%$ of chlorpyrifos \\
5. & T3 & Worms exposed to $0.375 \%$ of chlorpyrifos \\
\hline
\end{tabular}


Table.2 Total bacterial populations $\left(\mathrm{CFU} \times 104 \mathrm{ml}^{-1}\right)$ in E. fetida gut exposed to different concentrations of chlorpyrifos

\begin{tabular}{|c|c|c|c|c|c|c|c|}
\hline \multirow{2}{*}{$\begin{array}{l}\text { S. } \\
\text { No. }\end{array}$} & \multirow[t]{2}{*}{ Nutrient media } & \multirow[t]{2}{*}{ Vermicompost } & \multirow[t]{2}{*}{ Control } & \multicolumn{3}{|c|}{ Exposure to chlorpyrifos (in \% v/v) } & \multirow{2}{*}{$\begin{array}{c}\text { C.D. (at } \\
5 \% \text { ) }\end{array}$} \\
\hline & & & & 0.125 & 0.250 & 0.375 & \\
\hline 1. & MacConkey Agar & $45.00 \pm 3.61^{b}$ & $43.33 \pm 2.91^{b}$ & $36.00 \pm 2.31^{\mathrm{a}, \mathrm{b}}$ & $31.33 \pm 1.76^{\mathrm{a}}$ & $29.67 \pm 2.96^{\mathrm{a}}$ & 9.96 \\
\hline 2. & Luria Bertani & $39.00 \pm 4.72$ & $27.33 \pm 1.76$ & $18.33 \pm 0.882^{\mathrm{a}}$ & $14.00 \pm 2.31^{\mathrm{a}}$ & $10.67 \pm 2.19^{\mathrm{a}}$ & 8.60 \\
\hline 3. & R.S. Media & $35.00 \pm 1.73^{\mathrm{b}}$ & $32.33 \pm 2.03^{b}$ & $30.33 \pm 1.45^{\mathrm{b}}$ & $14.33 \pm 2.33^{\mathrm{a}}$ & $12.00 \pm 3.06^{\mathrm{a}}$ & 6.99 \\
\hline 4. & King's Media & $82.00 \pm 2.00$ & $71.33 \pm 2.40$ & $53.47 \pm 2.24^{\mathrm{a}}$ & $52.10 \pm 4.09^{\mathrm{a}}$ & $46.33 \pm 3.84^{\mathrm{a}}$ & 9.71 \\
\hline 5. & YEMA & $123.00 \pm 4.36^{\mathrm{a}}$ & $125.00 \pm 2.08^{\mathrm{a}}$ & $119.67 \pm 0.88^{\mathrm{a}}$ & $70.33 \pm 3.18$ & $34.00 \pm 2.65$ & 9.17 \\
\hline 6. & Jensen Media & $78.33 \pm 5.36^{\mathrm{c}}$ & $75.00 \pm 2.89^{b, c}$ & $65.67 \pm 3.28^{\mathrm{a}, \mathrm{b}}$ & $58.67 \pm 2.40^{\mathrm{a}}$ & $54.33 \pm 4.84^{\mathrm{a}}$ & 12.53 \\
\hline 7. & MalateMedia & $108.33 \pm 14.38$ & $126.67 \pm 8.11^{\mathrm{b}}$ & $120.00 \pm 3.46^{\mathrm{b}}$ & $77.33 \pm 12.02^{\mathrm{a}}$ & $76.33 \pm 2.96^{\mathrm{a}}$ & 29.87 \\
\hline 8. & Endo Agar Media & $49.33 \pm 5.81$ & $5.00 \pm 1.53^{\mathrm{a}}$ & $0.667 \pm 0.67^{\mathrm{a}}$ & $0.33 \pm 0.33^{\mathrm{a}}$ & $0.33 \pm 0.33^{\mathrm{a}}$ & 8.66 \\
\hline 9. & Nutrient Agar Media & $175.67 \pm 4.26^{\mathrm{c}}$ & $152.67 \pm 8.19^{\mathrm{b}, \mathrm{c}}$ & $132.33 \pm 6.49^{\mathrm{a}, \mathrm{b}}$ & $127.67 \pm 8.95^{\mathrm{a}}$ & $124.00 \pm 8.33^{\mathrm{a}}$ & 23.75 \\
\hline
\end{tabular}

Values with the same superscript in same row do not differ significantly 
Twenty one bacterial species viz. Acinetobacter sp., Alcaligenes faecalis, Bacillus brevis, B. cereus, B. lalerosporus, B. licheniformis, B. macerans, Bacillus sp., Corynebacterium sp., Enterobacter cloacae, Erwinia salicis, Flavobacterium aquatile, Flavobacterium sp., Klebsiella sp., Micrococcus luteus, $M$. kristinae, $M$. varians, Proteus myxofaciens, $P$. rennevi, $P$. vulgaris and Pseudomonas sp. has been previously reported by Owa et al., (2013).

\section{Impact of chlorpyrifos exposure on gut bacterial count}

Statistically the number of viable bacterial counts was at par in worms exposed to $0.125 \%, \quad 0.250 \%$ and $0.375 \%$ of chlorpyrifos; cultured on Mac Conkey Agar, Luria Bertani, King's Medium, Jensen medium, Endo Agar Medium and nutrient agar medium. It is worth noticing that in worms exposed to $0.250 \%$ and $0.375 \%$ and bacteria cultured on R. S. medium, statistically lower viable bacterial counts were observed in the gut samples in comparison to worms exposed to $0.125 \%$ and control. Significant difference in the gut bacterial samples of worms exposed even to lowest dose $(0.125 \%)$ cultured on Luria Bertani and King's Medium stamps the susceptibility of microbes towards chlorpyrifos exposure. However, nonsignificant difference in bacterial count of worms exposed to chlorpyrifos at highest concentration $(0.375 \%)$ cultured on YEMA, Malate, Jensen, R.S. Medium and Mac Conkey Agar Medium as compared to control approves the susceptibility of these bacteria to higher doses of chlorpyrifos only. When cultured on Mac Conkey Agar nonsignificant differences in total bacterial counts have been observed when compared with each other andcontrol. The bacterial counts on Luria Bertani were also at par in gut samples of worm treated with $0.125 \%$,
$0.25 \%$ and $0.375 \%$ chlorpyrifos. Significant lower bacterial counts on R.S. medium were observed in gut samples of worms exposed to $0.25 \%$ and $0.375 \%$ when compared with worms exposed to $0.125 \%$ chlorpyrifos (Table 2).

In conclusion, microbes are found to have endosymbiotic relationship with bacteria and thus, their vermicomposting capabilities are enhanced by the bacterial communities present in their gut. Enhanced bacterial counts have been observed in vermicompost when compared to those present in gut. Chlorpyrifos at higher concentrations alters the survival of bacterial communities. However, the present study leaves an avenue for finding the cause of chlorpyrifos induced toxicity to the bacterial population.

\section{Acknowledgement}

The authors are sincerely thankful to the Department of Zoology and HOD, Department of Microbiology to make available the facilities and timely help required for carrying out the research program.

\section{References}

Airaa, M., Olcinaa, J., Losadab, M.P. andDomínguez, J. 2016. Characterization of the bacterial communities of casts from Eisenia andrei fed with different substrates. Appl. Soil Ecol., 98: 103-111.

Andriuzzi, W.S., Ngo, P.T., Geisen, S., Keith, A.M., Dumack, K., Bolger. et al. 2016.Organic matter composition and the protest and nematode communities around an earthworm burrows. Biol. Fertil. Soils, 52: 91-100.

Bamidele, J.A., Idowu, A.B., Ademolu, K.O., and Atayese, A.O. 2014. Microbial diversity and digestive enzyme activities in the gut of earthworms found in sawmill industries in Abeokuta, Nigeria Rev. Biol. Trop. Int. J. Trop. Biol., 62(3): 1241- 
1249.

Boivin, G., Kolliker-Ott, U.M., Bale, J.S. and Bigler, F. 2006. Assessing the establishment potential of in undative biological control agents. Environmental Impact of Invertebrates for Biological Control of Arthropods: Methods and Risk Assessment, Eds F. Wallingford, 98-113.

Byzov, B.A., N.V. Khomyakov, S.A. Kharin and Kurakov, A.V. 2007. Fate of soil bacteria and fungi in the gut of earthworms. Eur. J. Soil. Biol., 43: 149156.

Esakkiammal, B. and Lakshmibai, L. 2013. Enumeration of bacterial population in the gut region of Eudrilus eugeniae. Int. J. Curr. Microbiol. App. Sci., 2(5): 267-270.

Fracchia, L., Doharmann, A.B., Martinotti, M.G. and Tebbe, C. 2006. Bacterial diversity in finished compost and vermicompost: differences revealed by cultivationindependent analyses of PCR-amplified 16S rRNA genes. Appl. Microbiol. Biotechnol., 71 :942-952.

Kadam, D.G. and Pathade, G.R. 2017. Studies on Selected Bacteria and Glycolytic Enzyme activities in the gut of Eudrilus eugeniae. Int. J. Curr. Microbiol. App. Sci., 6(4): 2256-2264.

Lavelle, P. 2011. Earthworms as ecosystem engineers. Encyclopedia of Agrophysics, eds J. Glinski, J. Horabik and J. Lipiec (NewYork, NY: Springer), 233-235.

Meharaj, I. and Manivannan, S. 2015. Effect of indigenous earthworm Lampito mauritii (Kinberg) and Perionyx excavates (Perrier) on microbial diversity and activity during bioconversion of poultry waste. Asian J. Plant Sci. Res., 5(7): 2226.

Owa, S.O., Olowoparja, S.B., Aladesida, A. and Dedeke, G.A. 2013. Enteric bacteria and fungi of the Eudrilid earthworm Libyodrilus violaceus. Afr. J. Agric. Res..,
8(17): 1760-1766.

Rao, J.V., Pavan, Y.S. and Madhavendra, S.S. 2003. Toxic effects of chlorpyrifos on morphology and acetylcholinesterase activity in the earthworm Eisenia foetida. Ecotoxicol. Environ. Saf., 54: 296-301.

Ravindran, B., Contreras-Ramos, S.M. and Sekaran, G. 2015. Changes in earthworm gut associated enzymes and microbial diversity on the treatment of fermented tannery waste using epigeic earthworm Eudrilus eugeniae. Ecol. Eng., 74: 394401.

Schrader, S., Rogasik, H., Onasch, I. and Jegou, D. 2007. Assessment of soil structural differentiation around earthworm burrows by means of X-ray computed tomography and scanning electron microscopy. Geoderma, 137: 378-387.

Thakuria, D., Schmidt, O., Finan, D., Egan, D. and Doohan, F.M. 2010. Gut wall bacteria of earthworms: a natural selection process. The ISME J., 4: 357-366.

Vega, H.B. and Victoria, D.E. 2009. Bacterial diversity in the digestive tract of earthworms (Oligocheta). J. Biol. Sci., 9(3): 192-199.

Yadav, J. and Gupta, R.K. 2017. Dynamics of Nutrient Profile during Vermicomposting. Eco. Env. \& Cons., 23(1): 516-521.

Yadav, J., Gupta, R.K. and Kumar D. 2017b. Chances in $\mathrm{C}$ : $\mathrm{N}$ of different substrates during vermicomposting. Eco. Env. \& Cons., 23(1): 368-372.

Yadav, J., Singh, D., Yadav, J. and Kumar, D. 2017a. Organophosphates and carbamates as inhibitors of acetylcholinesterase in Eisenia fetida. Poll. Res., 36(2): 278- 282.

Zhang, W., Chen, L., Liu, K., Chen, L., Lin, K., Guo, J., Liu, L., Cui, C., Yan, Z. 2014. Lead accumulations and toxic effects in earthworms (Eisenia fetida) in the presence of decabromodiphenyl ether. Environ. Sci. Poll. Res., 21: 3484-3490.

\section{How to cite this article:}

Jyoti Yadav, Dharambir Singh, Swati Sindhu, Rajesh Gera and Shefali. 2017. Enumeration of Gut Bacterial Population in Eisenia fetida Exposed to Chlorpyrifos. Int.J.Curr.Microbiol.App.Sci. 6(8): 824-830. doi: https://doi.org/10.20546/ijcmas.2017.608.104 